\title{
PATHOMORPHOLOGICAL PECULIARITIES OF LIVER OF FETUSES AND NEWBORNS BORN IN CONDITIONS OF HYPERTENSIVE DISEASE IN THE MOTHER
}

\author{
Zotova A. B., Zubova Y. O., Sherstiuk L. L., Khramova T. O., Nakonechna S. A.
}

Aim. The article is devoted to the study of pathomorphological features of fetal liver and newborns affected by chronic intrauterine hypoxia, which developed against maternal hypertension.

Materials and methods. The studies were performed on liver preparations of 18 fetuses and newborns from mothers with physiological pregnancy (group I) and 36 fetuses and newborns from mothers with stage II hypertension (group II) at the age of 37 weeks of gestation - the 1st day of postnatal life. In each case, three fragments were excised from the liver, and then the material was fixed in $10 \%$ formalin solution. Formalinfixed tissue compaction was achieved by conducting, through alcohols, increasing concentrations, celloidin, chloroform, and paraffin embedding. From the prepared blocks for serial color serial sections with a thickness of 4-5 microns were prepared. Micropreparations were stained with hematoxylin and eosin, picrofuxin by the van Gizon method, and by the Mallory method. The diameter of the hepatocytes and their nuclei, NPP, were calculated, and the number of single and double-nucleated hepatocytes was calculated. The material was studied on an «Olympus BX-41» microscope with a digital camera.

Results. The results of our study showed that the influence of chronic intrauterine hypoxia on the background of stage II hypertension led to the development of destructive-dystrophic changes in the liver tissue of the fetus and newborn. Structural and functional disorders, in turn, led to the activation of cellular regeneration mechanisms. In group II, the recovery of structural and functional integrity of the liver occurred due to an increase in the number of double-nucleated hepatocytes and manifested by an increase in their number almost 2-fold.

Conclusions. During the study of pathomorphological features of fetal liver and newborns it was found that stage II hypertension in the mother leads to the development of significant destructive-dystrophic changes in the tissue of fetal liver and newborns. The diameter of hepatocytes of fetuses and newborns of group II was significantly increased compared with group I $(24.3 \pm 2.4 \mu \mathrm{m}$ and $18.71 \pm 2.8 \mu \mathrm{m}$, respectively). The number of hepatocytes in the field of view in the fetuses and newborns of group II significantly decreased compared with group I $(214.8 \pm 22.80$ and $268.1 \pm 24.11$ cells, respectively). The ratio of the number of binucleate hepatocytes to the number of binucleate hepatocytes in fetuses and newborns of group II compared to group I increased 2.5 times $(0.08 \pm 0.02$ and $0.03 \pm 0.02$, respectively $)$

KEY WORDS: hypertension, fetuses, newborns, liver

\section{INFORMATION ABOUT AUTHORS}

Zotova Alla, Ph.D., assistant, V. N. Karazin Kharkiv National University, School of Medicine, 6, Svobody Sq., Kharkiv, Ukraine, 61022, e-mail: allazotova@karazin.ua, ORCID ID: http://orcid.org/0000-0002-0388-138X

Zubova Yevheniia, Ph.D., associate Professor, V. N. Karazin Kharkiv National University, School of Medicine, 6, Svobody Sq., Kharkiv, Ukraine, 61022, e-mail: zubova@karazin.ua, ORCID ID: http//orcid.org/0000-0001-6820-5000 Sherstiuk Liudmyla, assistant, V. N. Karazin Kharkiv National University, School of Medicine, 6, Svobody Sq., Kharkiv, Ukraine, 61022, e-mail: sunny.sherstiuk@gmail.com

Khramova Tetyana, Ph.D., Associate Professor, V. N. Karazin Kharkiv National University, School of Medicine, 6, Svobody Sq.,bKharkiv, Ukraine, 61022, e-mail: tetianakhramova@karazin.ua, ORCID ID: http//orcid.org/0000-0001$5945-6852$

Nakonechna Svitlana, Ph.D., Associate Professor, V. N. Karazin Kharkiv National University, School of Medicine, 6 , Svobody Sq., Kharkiv, Ukraine, 61022, e-mail: s.nakonechna@karazin.ua, ORCID ID: http//orcid.org/0000-0002-47181465

\section{INTRODUCTION}

According to the World Health Organization, hypertensive disorders during pregnancy occupy one of the first places in

(C) Zotova A. B., Zubova Y. O., Sherstiuk L. L.,

Khramova T. O., Nakonechna S. A., 2020 the structure of maternal mortality in the world and make up 20-33\% [1,2].

Among the various hypertensive states in pregnant women an important place is hypertensive disease (HD). This pathology is quite widespread in this category of patients, 
and pregnancy is accompanied by a considerable number of serious complications, with fetuses and newborns very often suffering, and the level of perinatal losses is high $[3,4]$.

In recent years, in the structure of extragenital disorders of pregnant women, one of the leading places is occupied by HD. Over the last 5 years in Ukraine the level of this pathology in pregnant women has increased [5].

In hypertension of pregnant women, chronic fetoplacental insufficiency (FPI) is formed, which is the cause of the development of chronic intrauterine hypoxia in the fetus [3]. Children of these women are prone to developing metabolic and hormonal disorders and cardiovascular pathology [6, 7].

According to the official statistics, the diseases of the gastrointestinal tract are quite common in the children's population of Ukraine. In the structure of gastroenterological pathology in children, first, there is a predominance of chronic inflammatory diseases, characterized by rejuvenation, especially in recent times, and, secondly, a significant number of cases account for liver pathology [8].

The works devoted to hypoxic damage of a liver at newborns, in the majority of cases have clinical orientation and do not have sufficient morphological confirmation. Thus, the chosen topic is relevant, because in modern medicine this problem has not been sufficiently studied and remains open.

\section{OBJECTIVE}

The aim of this study was to identify the pathomorphological features of the liver of the fetus and newborn born in conditions of maternal hypertension.

\section{MATERIALS AND METHODS OF RESEARCH}

Studies were performed on liver preparations of 18 fetuses and newborns from mothers with physiological pregnancy (group I) and 36 fetuses and newborns from mothers with stage II hypertension (group II) at the age of 37 weeks of gestation - the 1st day of postnatal life during sectional studies on the basis of the Municipal Non-profit Company «Municipal Perinatal Center». The diagnosis of HD was established according to the Order of the Ministry of Health № 384 of May 24,
2012 «On approval and implementation of medical and technological documents on standardization of care in arterial hypertension (adapted clinical guideline «Arterial hypertension» in pregnant women). The studies were conducted in accordance with the requirements of the Instruction on Forensic Expertise (Order of the Ministry of Health of Ukraine No. 6 of 17.01.1995), in accordance with the requirements and norms, the standard provisions on ethics of the Ministry of Health of Ukraine № 690 of 23.09.2009, «The procedure for the removal of biological objects from the dead, whose bodies are subject to forensic examination and pathomorphological research, for scientific purposes» (2018).

Material of the study was the liver of the fetus and newborn of both groups obtained during the autopsy. In each case, three fragments were excised from the liver, and then the material was fixed in $10 \%$ formalin solution. Formalin-fixed tissue compaction was achieved by conducting, through alcohols, increasing concentrations, celloidin, chloroform, and paraffin embedding. From the prepared blocks for serial color serial sections with a thickness of 4-5 microns were prepared. Micropreparations were stained with hematoxylin and eosin, picrofuxin by the van Gizon method, and by the Mallory method. The material was studied on an «Olympus BX-41» microscope with a digital camera.

The diameter of the hepatocytes and their nuclei was calculated using a standard microlinear, which was inserted into the eyepiece of the microscope at magnification of the microscope $\times 200$. In each preparation, 50 measurements were performed. The number of one- and two-nucleus hepatocytes was calculated using the Avtandilov microscopic morphometric grid, which consisted of 100 equally spaced points and was inserted into the microscope eyepiece at magnification of the microscope $\times 200$. The number of points that fell on one- and twonucleus hepatocytes was calculated. In each preparation, 50 measurements were performed [9].

Statistical processing of the results was carried out using the standard package of statistical programs «STATISTICA 10.0» and «MS Excel». The arithmetic mean (M), standard error of the mean (m) were 
calculated for the obtained results. A simple Student's test ( $\mathrm{t}$ ) was used to assess the significance of differences between groups

\section{RESULTS OF THE STUDY AND THEIR DISCUSSION}

Macroscopically, group I liver had a thin shiny translucent capsule and was elastic to the touch. The incision of the liver tissue was red-brown in color, homogeneous, with properly developed and unevenly fullblooded hepatic veins.
Microscopically, properly formed histoarchitectonics in the form of a beamradial structure were observed in the liver of group I. In the center of the liver lobes were unevenly full-blooded central veins. The sinusoids had a moderately curved appearance and were also unevenly fullblooded. Also, single stellar Kupffer cells and small foci of extramedullary hematopoiesis were detected throughout the liver parenchyma (Fig. 1).

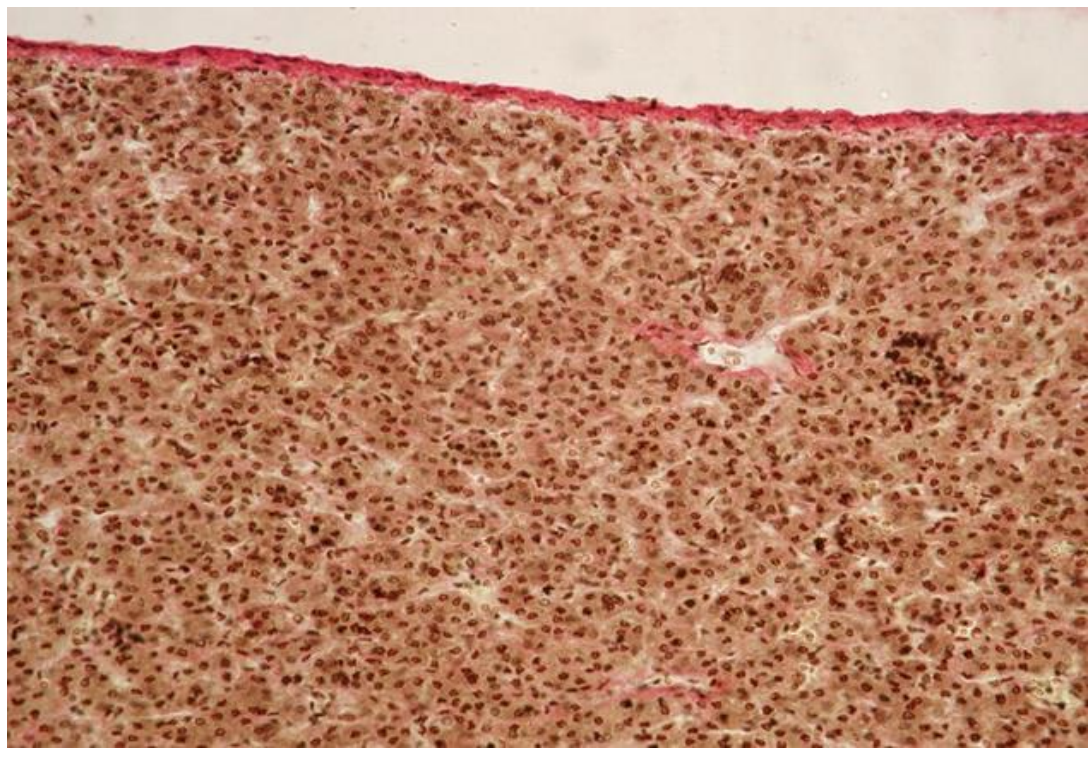

Fig. 1. Liver of the newborn group I. Normal histoarchitectonics of the parenchyma, unevenly full-blooded sinusoids, small foci of extramedullary hematopoiesis. Van Gizon coloring. $\times 200$.

Hepatocytes were with eosinophilic granular cytoplasm and a rounded basophilic nucleus. The diameter of the hepatocytes was $18.71 \pm 2.8 \mu \mathrm{m}$, the diameter of the hepatocyte nuclei was $6.08 \pm 0.5 \mu \mathrm{m}$, the nuclear cytoplasmic indicator was $0.32 \pm$ 0.01 . The total number of hepatocytes in one field of view at magnification $\times 200$ was $268.1 \pm 24.11$ cells, among which the number of mononuclear hepatocytes $-259.8 \pm 23.15$ cells and the number of binucleate hepatocytes $-8.2 \pm 1.1$ cells. The ratio of the number of binucleate hepatocytes to the number of mononuclear hepatocytes in the control group was $0.03 \pm 0.02$.

Group I liver had a moderately developed stroma mainly in the portal tract area. The stroma was represented by loose tufts of collagen fibers with moderate lymphohistiocytic infiltration (Fig. 2).
The morphological examination of group I liver indicates its maturity with normally formed components of the parenchyma and stroma.

Group II liver macroscopically had a thin shiny translucent capsule and was tightly elastic to the touch. The incision of the liver tissue was red-yellow in color, fine-grained, with properly developed and unevenly fullblooded hepatic veins.

Microscopically, in the liver of group II there was a violation of histoarchitectonics in the form of discomplexation and fusion of beams. In the center of the liver lobes were unevenly full-blooded central veins. The sinusoids had a curved appearance, and were sharply full-blooded. Kupffer stellate cells and multiple foci of extramedullary hematopoiesis were detected throughout the liver parenchyma (Fig. 3). 


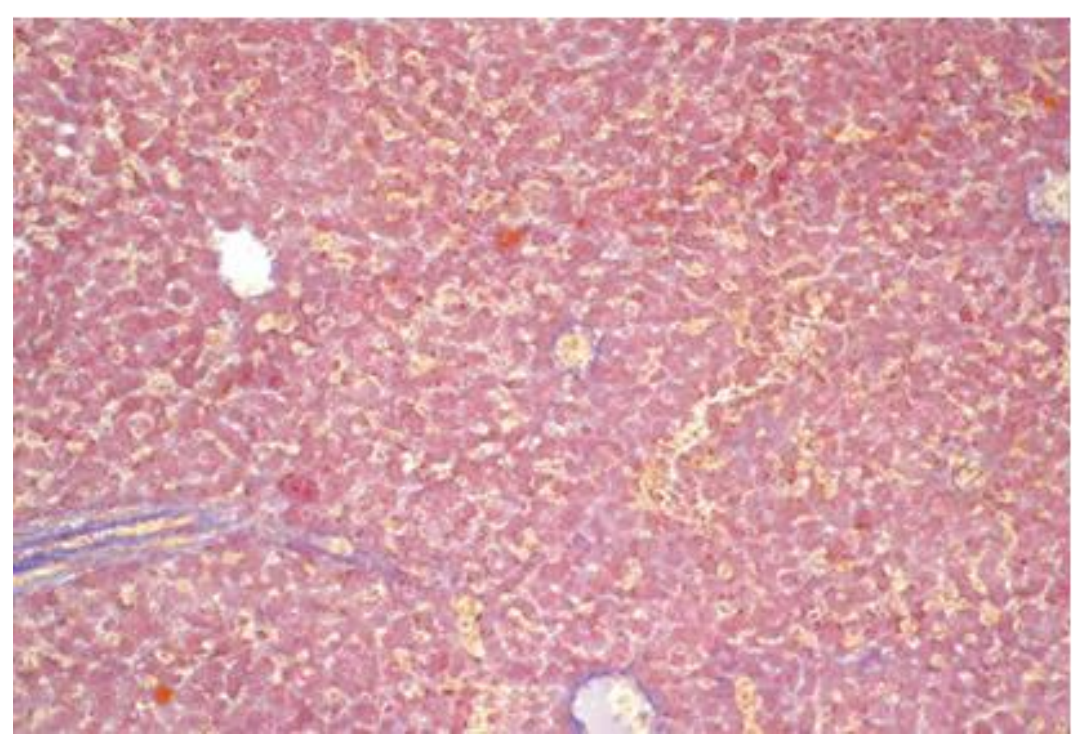

Fig. 2. Liver of the newborn group I. Moderate stroma development in the portal tract area. Coloring for Mallory. $\times 100$.

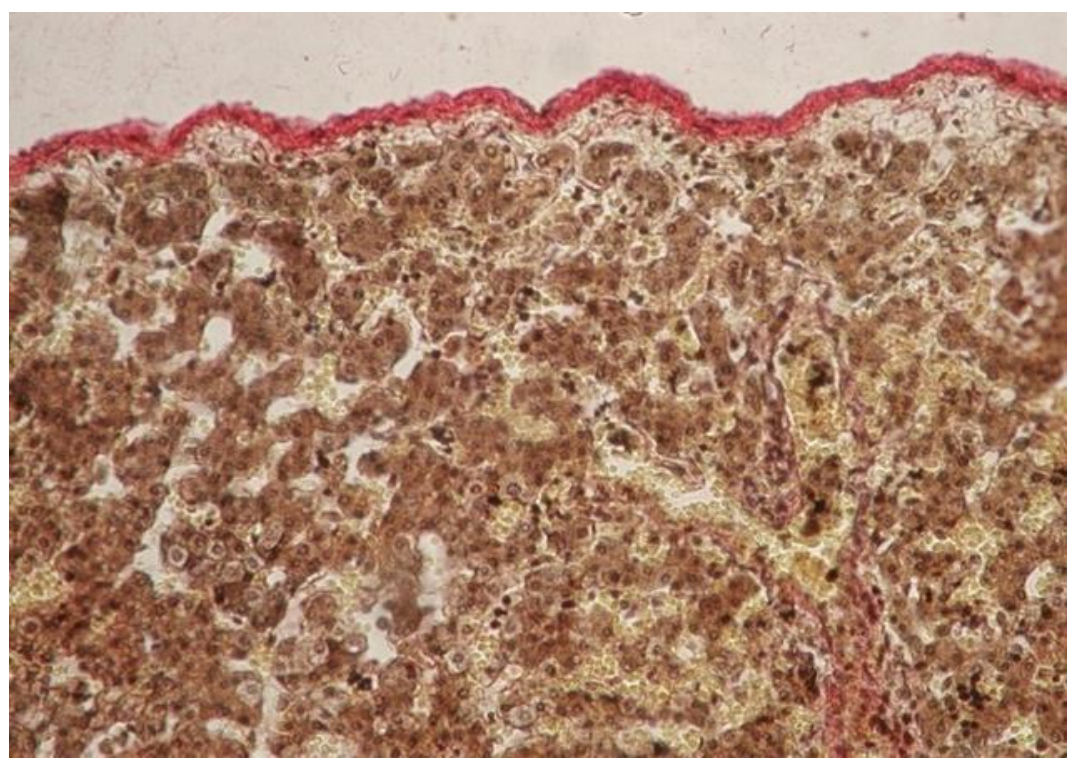

Fig. 3. Liver of the newborn group II. Beam discomplexation, unevenly full-blooded sinusoids, multiple small foci of extramedullary hematopoiesis. Van Gizon coloring. $\times 200$.

Hepatocytes had light foamy cytoplasm and rounded hypochromic nuclei. Periportal in the hepatocytes revealed small fat vacuoles in the form of optical voids. The diameter of the hepatocytes was $24.3 \pm 2.4 \mu \mathrm{m}$, the diameter of the hepatocyte nuclei was $7.12 \pm$ $0.2 \mu \mathrm{m}$, the nuclear cytoplasmic indicator was $0.29 \pm 0.01$. The total number of hepatocytes in one field of view at magnification $\times 200$ was $214.8 \pm 22.80$ cells, among which the number of mononuclear hepatocytes was
$198.2 \pm 18.8$ cells, and the number of binucleate hepatocytes was $16.2 \pm 1.8$ cells. The ratio of the number of binucleate hepatocytes to the number of mononuclear hepatocytes in group II was $0.08 \pm 0.02$.

In the liver of group II, considerable growth of stroma was noticed, especially in the area of portal tracts in the form of dense tufts of collagen fibers with moderate lymphohistiocytic infiltration (Fig. 4). 


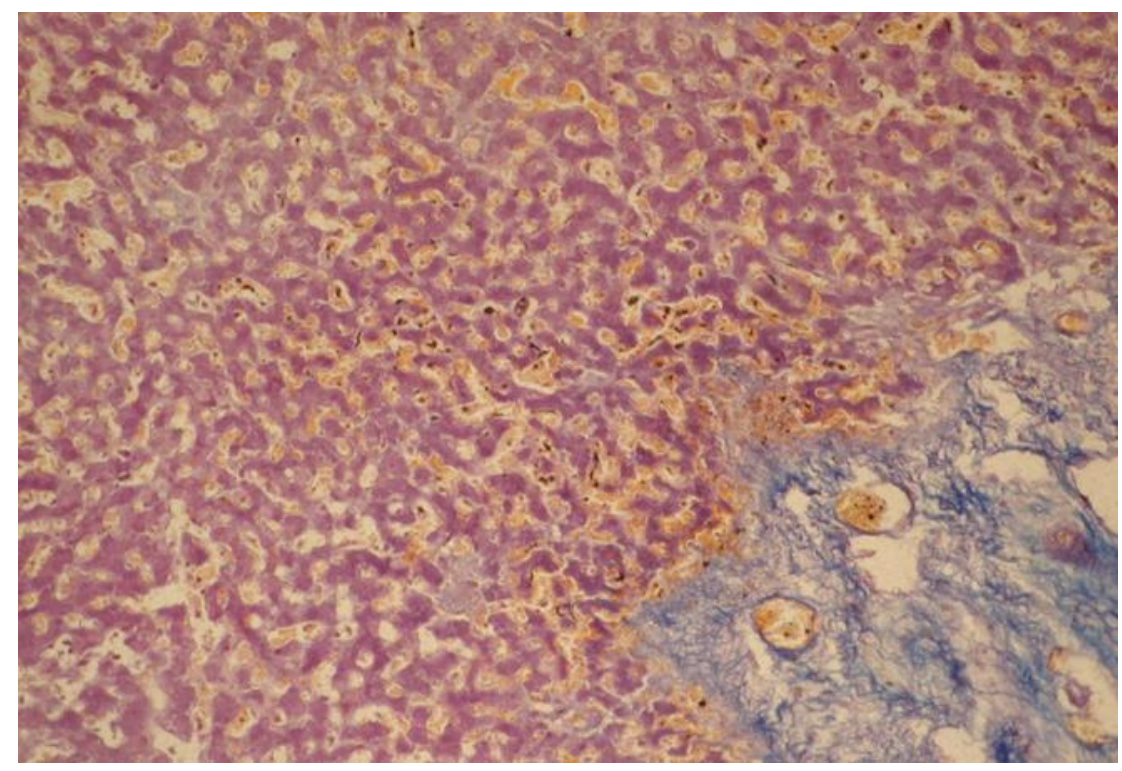

Fig. 4. Liver of the newborn group II. Growth of portal stroma stroma. Coloring for Mallory. $\times 100$.

Analyzing the morphometric parameters of hepatocytes in group I and group II, it can be said that the diameter of hepatocytes in group II was significantly larger $(p<0.05)$ compared to group I. In group II, hepatocyte size had a significant difference $(p<0.05)$ with group I due to dystrophic changes in cells, which, in our view, is caused by the effect of such a damaging factor as hypoxia caused by maternal hypertension. The number of hepatocytes in the field of view in the fetuses and newborns of group II had significantly lower rates $(p<0.05)$ compared with group I.

It should be noted that in group II in the stroma of the liver when staining for Mallory revealed fields of view in which the collagen fibers were determined and there were no elastic fibers. The sclerotic changes revealed in the histological examination of the micropreparations in the liver of fetuses and newborns of group II in comparison with group I due to the fact that in group II there was an aggressive damaging factor represented by chronic intrauterine hypoxia, characterized by prolonged exposure and chronostatic condition has previously been described by scientists in pregnant women with diagnosed hypertension [10].

The study performed in our study showed that in group II there was a significant increase $(p<0.05)$ in the ratio of the number of binucleate hepatocytes to the number of mononuclear hepatocytes. This suggests that this phenomenon is directly related to the restoration of the structure of the organ.

A certain number of binucleate hepatocytes is found in the liver in normal. An increase in their number after exposure to various damaging factors has been identified by domestic and foreign researchers [11, 12]. Our morphometric study showed that there was a significant $(p<0.05)$ increase in the number of binucleate hepatocytes found in groups near vessels and in the form of single forms in the liver of fetuses and newborns of group II. In our opinion, this suggests that this phenomenon is directly related to the restoration of the structure of the organ. It also indicates that hypoxic damage can cause not only damage to the parenchyma, but also cell proliferation as a regenerative response. To date, it is believed that the formation of binucleate hepatocytes from mononuclear forms in reparative regeneration is a reserve of polyploidization [13].

The results of our study showed that the influence of chronic intrauterine hypoxia on the background of stage II hypertension led to the development of destructive-dystrophic changes in the liver tissue of the fetus and newborn. Structural and functional disorders, in turn, led to the activation of cellular regeneration mechanisms. In group II, the recovery of structural and functional integrity of the liver occurred due to an increase in the number of binucleate hepatocytes and 
manifested by an increase in their number almost 2-fold.

Thus, the results of the study expand the knowledge about the mechanisms of cellular regeneration and structural reorganization of the liver in offspring affected by chronic intrauterine hypoxia on the background of stage II maternal hypertension.

\section{CONCLUSIONS}

1. Stage II hypertension in the mother leads to the development of significant destructive-dystrophic changes in the liver tissue of the fetus and newborn.

2. The diameter of hepatocytes of fetuses and newborns of group II is significantly increased compared to group I $(24.3 \pm 2.4 \mu \mathrm{m} \quad$ and $18.71 \pm 2.8 \mu \mathrm{m}$, respectively).

3. The number of hepatocytes in the field of view in fetuses and newborns of group II is significantly reduced compared with group I $(214.8 \pm 22.80$ and $268.1 \pm$ 24.11 cells, respectively).
4. The ratio of the number of binucleate hepatocytes to the number of mononuclear hepatocytes in fetuses and newborns of group II compared to group I increased 2.5 times $(0.08 \pm 0.02$ and $0.03 \pm 0.02$, respectively).

\section{PROSPECTS FOR FURTHER RESEARCH}

It is promising to study the immunohistochemical features of fetal liver and newborns that developed under maternal hypertension.

\section{THE RELATIONSHIP OF THE PUBLICATION TO THE PLANNED RESEARCH WORK}

The study was carried out within the framework of the research work of the Department of Human Anatomy of the VN Karazin Kharkiv National University «Detecting the Impact of Maternal Pathology on the Development of the Fetal and Newborn Organism», State Registration Number 0117 U004838.

\section{REFERENCES}

1. Mushak, N. I. (2017). Obstetric and perinatal complications in pregnant women with arterial hypertension in conditions of iodine deficiency. Family medicine, № 5(73), 118-128 [In Ukrainian]. doi: https://doi.org/10.30841/2307-5112.5(73).2017.123404.

2. Mudjari, N. S., Samsu, N. (2015). Management of hypertension in pregnancy. Acta. Med. Indones, Vol. 47(1), 78-86. Retrieved from https://pdfs.semanticscholar.org/6d85/fc8743e2e2eec3562daea70178baf6d70e17.pdf.

3. Bogdanova. R. F., Amirova, V. R., Galimov, A. I. (2015). Features of the course of pregnancy in women with cardiovascular pathology. Medical Bulletin of Bashkortostan, Vol. 12, № 4 (70), 35-38 [In Russian].

4. Ghulmiyyah, L., Sibai, B. (2012). Maternal mortality from preeclampsia/eclampsia. Semin Perinatol, Vol. 36 (1), 56-59. doi: 10.1053/j.semperi.2011.09.011.

5. Medved, V. I. (2018). The main issues of extragenital pathologists. Medical Aspects of Health's Health, № 2 (115), 5-11 [In Russian].

6. Chingaeva, G. N., Raeva, M. I., Malikova, D. A., Kalaubekova, A. A. (2013). Arterial hypertension in pregnant women: classification and principles of therapy from the perspective of evidence-based medicine. Bulletin of KAZNMU, №3 (1), 97-103 [In Russian].

7. Seliem, W., Falk, M., Shadbolt, B. [et al.] (2007). Antenatal and postnatal risk factors for neonatal hypertension and infant follow-up. Pediatr. Nephrology, Vol. 22, № 12, 2081-2087. doi: 10.1007/s00467007-0603-2.

8. Marushko, R. V. (2014). Risk factors and prognosis for the development of functional and chronic inflammatory bowel disease in young children. Perinatology and pediatrics, № 1 (57), 51-55 [In Ukrainian].

9. Avtandilov, G. G. (2002). Fundamentals of quantitative pathological anatomy: textbook. Allowance. M .: Medicine. 240 p. [In Russian].

10. Yakovleva, E. A., Demina, O. V., Babadzhanyan, E. N. (2017). Placental dysfunction. International Medical Journal, № 2, 47-51 [In Russian].

11. Nowrouzi, F., Azadbakht, M. (2017). Hepatocellular and developmental influences of early postnatal indomethacin in mice. Bratisl. Med. J., Vol.118 (1), 44-50. doi:10.4149/BLL_2017_009.

12.Zuevskij, V. P., Soltys, T. V. (2000). Binuclear hepatocytes as a form of intracellular regeneration in experimental opisthorchiasis. Biomedical and environmental health problems of the population of the North: Sat. Vseros materials. scientific - practical conf. Section I. Surgut, Part I., 204-205 [In Russian]. 
13. Patricolo, M., Paolocci, N., Zangari, A. [et al]. (1996). Hepatic resection in the rat fetal rabbit. Histological comparision of tissue regeneration in the fetus versus the adult. Ninerva. Chir., Vol. 51 (11), 971- 977.

\section{ПАТОМОРФОЛОГІЧНІ ОСОБЛИВОСТІ ПЕЧІНКИ ПЛОДІВ ТА НОВОНАРОДЖЕНИХ ВИНОШЕНИХ В УМОВАХ ГІПЕРТОНІЧНОЇ ХВОРОБИ У МАТЕРІ}

Зотова А. Б., Зубова С. О., Шерстюк Л. Л., Храмова Т. О., Наконечна С. А.

Мета. Стаття присвячена вивченню патоморфологічних особливостей печінки плодів та новонароджених, котрі зазнали впливу хронічної внутрішньоутробної гіпоксії, що розвивалась на фоні материнської гіпертонічної хвороби.

Матеріали та методи. Дослідження проводили на препаратах печінки 18 плодів та новонароджених від матерів із фізіологічною вагітністю (група I) та 36 плодів та новонароджених від матерів із гіпертонічною хворобою II стадії (група II) у віці 37 тижнів гестації - 1-ша доба постнатального життя. У кожному випадку з печінки вирізали по три фрагменти, а потім матеріал фіксували в $10 \%$ розчині формаліну. Ущільнення тканин, фіксованих у формаліні, досягалося проведенням через спирти зростаючої концентрації, целоїдин, хлороформ і заливкою в парафін. 3 приготованих блоків для подальшого забарвлення готувалися серійні зрізи товщиною 4-5 мкм. Мікропрепарати забарвлювалися гематоксиліном і еозином, пікрофуксином за методом ван Гізона, та за методом Маллорі. Обчислювали діаметр гепатоцитів та їх ядер, ядерно-цитоплазматичний показник, підраховували кількість одно- та двоядерних гепатоцитів. Матеріал вивчали на мікроскопі «Olympus BX-41» 3 цифровою фотокамерою.

Результати. Отримані нами результати дослідження свідчили про те, що вплив хронічної внутрішньоутробної гіпоксії на фоні гіпертонічної хвороби II стадії у матері призводив до розвитку деструктивно-дистрофічних змін в тканині печінки плодів i новонароджених. Структурнофункціональні порушення, в свою чергу, призводили до активації механізмів клітинної регенерації. В групі II відновлення структурно-функціональної цілісності печінки відбувалося за рахунок збільшення кількості двоядерних гепатоцитів та проявлялося підвищенням їх кількості майже в 2 рази.

Висновки. Під час вивчення патоморфологічних особливостей печінки плодів та новонароджених було встановлено, що гіпертонічна хвороба II стадії у матері призводить до розвитку значних деструктивно-дистрофічних змін в тканині печінки плодів та новонароджених. Діаметр гепатоцитів плодів та новонароджених групи II значимо збільшується в порівнянні з групою I $(24,3 \pm 2,4$ мкм та $18,71 \pm 2,8$ мкм відповідно). Кількість гепатоцитів у полі зору у плодів та новонароджених групи II значимо зменшується в порівнянні $з$ групою I $(214,8 \pm 22,80$ та $268,1 \pm 24,11$ клітин відповідно). Відношення числа двоядерних гепатоцитів до числа одноядерних гепатоцитів у плодів та новонароджених групи II в порівнянні з групою I збільшується в 2,5 рази $(0,08 \pm 0,02$ та $0,03 \pm 0,02$ відповідно).

КЛЮЧОВІ СЛОВА: гіпертонічна хвороба, плоди, новонароджені, печінка

\section{ІНФОРМАЦІЯ ПРО АВТОРІВ}

Зотова Алла Борисівна, к.мед.н., асистент, Харківський національний університет імені В. Н. Каразіна, медичний факультет, площа Свободи, 6, Харків, Україна, 61022, e-mail: allazotova@karazin.ua, ORCID ID: http//orcid.org/0000-0001-5859-1796

Зубова Свгенія Олегівна, к.мед.н., доцент, Харківський національний університет імені В. Н. Каразіна, медичний факультет, площа Свободи, 6, Харків, Україна, 61022, e-mail: zubova@karazin.ua, ORCID ID: http//orcid.org/0000-0001-6820-5000

Шерстюк Людмила Леонідівна, к.мед.н., асистент, Харківський національний університет імені В. Н. Каразіна, медичний факультет, площа Свободи, 6, Харків, Україна, 61022, e-mail: sunny.sherstiuk@ gmail.com

Храмова Тетяна Олександрівна, к.мед.н., доцент, Харківський національний університет імені В. Н. Каразіна, медичний факультет, площа Свободи, 6, Харків, Україна, 61022, e-mail: tetianakhramova@karazin.ua, ORCID ID: http//orcid.org/0000-0001-5945-6852

Наконечна Світлана Анатоліївна, к.біол.н., доцент, Харківський національний університет імені В. Н. Каразіна, медичний факультет, площа Свободи, 6, Харків, Україна, 61022, e-mail: s.nakonechna@karazin.ua, ORCID ID: http//orcid.org/0000-0002-4718-1465 


\section{ПАТОМОРФОЛОГИЧЕСКИЕ ОСОБЕННОСТИ ПЕЧЕНИ ПЛОДОВ И НОВОРОЖДЕННЫХ ВЫНОШЕНЫХ В УСЛОВИЯХ ГИПЕРТОНИЧЕСКОЙ БОЛЕЗНИ У МАТЕРИ}

Зотова А. Б., Зубова Е. О., Шерстюк Л. Л., Храмова Т. А., Наконечная С. А.

Цель. Статья посвящена изучению патоморфологических особенностей печени плодов и новорожденных, которые подверглись воздействию хронической внутриутробной гипоксии, развивающейся на фоне материнской гипертонической болезни.

Материалы и методы. Исследования проводили на препаратах печени 18 плодов и новорожденных от матерей с физиологической беременностью (группа I) и 36 плодов и новорожденных от матерей с гипертонической болезнью II стадии (группа II) в возрасте 37 недель гестации - 1-е сутки постнатальной жизни. В каждом случае из печени вырезали по три фрагмента, а затем материал фиксировали в $10 \%$ растворе формалина. Уплотнение тканей, фиксированных в формалине, достигалось проведением через спирты возрастающей концентрации, целлоидин, хлороформ и заливкой в парафин. С приготовленных блоков для последующей окраски готовились серийные срезы толщиной 4-5 мкм. Микропрепараты окрашивались гематоксилином и эозином, пикрофуксином по методу ван Гизона, и по методу Маллори. Вычисляли диаметр гепатоцитов и их ядер, ядерно-цитоплазматический показатель, подсчитывали количество одно- и двухъядерных гепатоцитов. Материал изучали на микроскопе «Olympus BX-41» с цифровой фотокамерой.

Результаты. Полученные нами результаты исследования свидетельствовали о том, что влияние хронической внутриутробной гипоксии на фоне гипертонической болезни II стадии у матери приводило к развитию деструктивно-дистрофических изменений в ткани печени плодов и новорожденных. Структурно-функциональные нарушения, в свою очередь, приводили к активации механизмов клеточной регенерации. В группе II восстановления структурно-функциональной целостности печени происходило за счет увеличения количества двухъядерных гепатоцитов и проявлялось повышением их количества почти в 2 раза.

Выводы. При изучении патоморфологических особенностей печени плодов и новорожденных было установлено, что гипертоническая болезнь матери приводит к развитию значительных деструктивно-дистрофических изменений в ткани печени плодов и новорожденных. Диаметр гепатоцитов плодов и новорожденных группы II значительно увеличивается по сравнению с группой I $(24,3 \pm 2,4$ мкм и $18,71 \pm 2,8$ мкм соответственно). Количество гепатоцитов в поле зрения у плодов и новорожденных группы II значительно уменьшается по сравнению с группой I $(214,8 \pm 22,80$ и $268,1 \pm 24,11$ клеток соответственно). Отношение числа двухъядерных гепатоцитов к числу одноядерных гепатоцитов у плодов и новорожденных группы II по сравнению с группой I увеличивается в 2,5 раза $(0,08 \pm 0,02$ и $0,03 \pm 0,02$ соответственно).

КЛЮЧЕВЫЕ СЛОВА: гипертоническая болезнь, плоды, новорожденные, печень

\section{ИНФОРМАЦИЯ ОБ АВТОРАХ}

Зотова Алла Борисовна, к.мед.н., ассистент, Харьковский национальный университет имени В. Н. Каразина, медицинский факультет, площадь Свободы, 6, Харьков, Украина, 61022, e-mail: allazotova@karazin.ua, ORCID ID: http//orcid.org/0000-0001-5859-1796

Зубова Евгения Олеговна, к.мед.н., доцент, Харьковский национальный университет имени В. Н. Каразина, медицинский факультет, площадь Свободы, 6, Харьков, Украина, 61022, e-mail: zubova@karazin.ua, ORCID ID: http//orcid.org/0000-0001-6820-5000

Шерстюк Людмила Леонидовна, к.мед.н., ассистент, Харьковский национальный университет имени В. Н. Каразина, медицинский факультет, площадь Свободы, 6, Харьков, Украина, 61022, e-mail: sunny.sherstiuk@gmail.com

Храмова Татьяна Александровна, к.мед.н., доцент, Харьковский национальный университет имени В. Н. Каразина, медицинский факультет, площадь Свободы, 6, Харьков, Украина, 61022, e-mail: tetianakhramova@karazin.ua, ORCID ID: http//orcid.org/0000-0001-5945-6852

Наконечная Светлана Анатольевна, к.биол.н., доцент, Харьковский национальный университет имени В. Н. Каразина, медицинский факультет, площадь Свободы, 6, Харьков, Украина, 61022, e-mail: s.nakonechna@karazin.ua, ORCID ID: http//orcid.org/0000-0002-4718-1465 